\section{Preposition STRANDING and ORPHANING: The case of bare prepositions in French}

In their keynote contribution, Poplack, Zentz \& Dion (henceforth PZD; Poplack, Zentz \& Dion, 2011, this issue) propose an interesting "scientific test of convergence" (under section heading: "Introduction") which contains criteria to check whether a particular feature in a given language in contact with another one is due to language contact or not. This is a valiant endeavor with a laudable goal. It is valiant because the answer to this question requires a complex investigation of the languages at issue. It is laudable since it is commonly believed that a given feature of a language in contact with another one is the result of convergence. This belief however is, in general, only a mere conjecture due to superficial similarities of the features at issue, for which no empirical evidence is provided. Yet, there is no doubt that PZD accomplish their endeavor in an outstanding manner. Based on a thorough study of substantial data from Canadian French and Canadian English, they demonstrate in a convincing way how it is possible to reveal whether a given feature is contact-induced or not.

Nevertheless, there are two major issues I would like to address. The first concerns PZD's test of convergence, the second refers to the use and the status of bare prepositions in French, the topic chosen by PZD to assess the possibility of contact-induced change.

Regarding the first issue, PZD outline a kind of checklist with five criteria which can serve as a test for assessing whether a given feature of a language is contact-induced or not. By doing so they implicitly - and rightly too - ascribe the burden of proof to those who claim that a given feature is contact-induced. As for the status of the proposed criteria, I wonder whether they are hierarchically ordered or whether some of these criteria are more pertinent than others. Must only one or rather all of these criteria be fulfilled in order to falsify the assumption of convergence? Presumably, if one of the proposed criteria is met, the feature at issue is not the result of contact-induced change. This directly relates to my second issue, namely phrasefinal or bare prepositions. ${ }^{1}$

\footnotetext{
1 Although PZD use the term "phrase-final prepositions", I prefer "bare prepositions" given that these prepositions may also occur in contexts where they are not in a sentence-final position, as shown in the following examples taken from Grevisse and Goose (2007, p. 1329f.):

(i) a. Nous sortirons avec tout à 1'heure. "We will go out with (him) later."
}

GEORG A. KAISER

Fachbereich Sprachwissenschaft,

Universität Konstanz

georg.kaiser@uni-konstanz.de

According to PZD, the use of such bare prepositions is an apparently stereotypical and stigmatized feature of North American, and especially Canadian, French. Given their complexity, the conditions for the use of these prepositions and the contexts of their occurrence are only "poorly understood" (Rowlett, 2007, p. 61) and not always satisfactorily illustrated in the relevant literature. To some degree, this is also reflected in PZD's contribution. It is, hence, worthwhile to shed some light on this issue. PZD point out that two contexts should be distinguished with regard to bare prepositions: relative clauses vs. contexts other than relative clauses. The first context is illustrated in (1) (Jones, 1996, p. 517; Rowlett, 2007, p. 60, note 1):
(1) a. la fille que je suis sorti avec "the girl with whom I went out"
b. le mec que je t'ai vu avec "the bloke I saw you with"

At first sight, these French examples appear to parallel the widely-used PREPOSITION STRANDING in English. In the latter language, it is generally assumed that the complement of the preposition is preposed by whmovement to CP leaving a trace behind (Jones, 1996, p. 518; Radford, 1997 , p. 278): ${ }^{2}$

\section{(2) [NP the girl [ $\mathrm{CP}_{\uparrow}$ that [s I went out with who]}

However, as briefly discussed by PZD (under section heading: "Stranding or orphaning"), there is evidence that the French constructions in (1) are NoT derived by $w h$-movement. One argument presented against such an analysis relies on the fact that constructions like (1), unlike English constructions such as (2), are possible only with a highly restricted set of prepositions; for instance, they are not possible with prepositions categorized by PZD as "semantically weak" such as à "to" and de "for". Another

b. Il court derrière pour la rattraper. "He runs behind (her) to catch her."

2 Alternatively, the preposition may move together with its complement to CP. This strategy, called PIED PIPING, is possible in both languages:

(i) a. la fille avec qui (que) je suis sorti

b. the girl with whom I went out 
argument is that some prepositions must differ in form when used in a construction like (1) (Jones, 1996, p. 518):

(3) a. *la maison que je suis entré dans

b. la maison que je suis entré dedans "the house I entered"

There is, thus, strong evidence that constructions like (1) structurally differ from constructions like those in (2) and do not represent instances of preposition stranding. The omitted argument of the preposition is therefore considered a null pronominal element rather than a trace.

In this respect, constructions like (1) resemble the second type of construction containing bare prepositions in French. The latter, called PREPOSITION ORPHANING, is highly elliptical and often regarded as the "absolute" or "intransitive" use of prepositions. The common analysis for this construction is that the argument of the preposition is deleted (Jones, 1996, p. 386; Porquier 2001, p. 124; Riegel, Pellat \& Rioul, 2008, p. 224).

(4) a. Il a joué avec.

"He played with (him/her/it)."

b. Il est venu sans.

"He came without (him/her/it)."

c. On a couru après.

"He ran after (him/her/it)."

As far as English is concerned, Jones (1996, p. 386) outlines that bare prepositions of this type are "very common" and gives the following examples:

(5) a. John went out.

b. Bill fell down.

Surprisingly enough, Poplack and Levey (2010, p. 405) claim the contrary by affirming that "orphaning is not admissible in English". The facts actually get clearer in PZD's study which shows that orphaning in English is restricted to a specific set of prepositions and that it is "generally not admissible in English with the translations of the relevant French prepositions" (under section heading: "Comparison with a native French model: Preposition orphaning").

However, as for French, PZD's presentation concerning the use of bare prepositions is to some extent misleading. Notice that PZD base their investigation of bare prepositions in Quebec French on the observation that these prepositions are "prescriptively unacceptable in French", while being "the norm in English" (under section heading: "Introduction"). This statement is, however, problematic in three respects. First, it remains unclear why the - alleged-existence of such a prescriptive rule should say anything about the presence of bare prepositions in French. Quite to the contrary, the condemnation of bare prepositions by prescriptive grammars rather represents clear evidence for the existence of such prepositions. Otherwise, there would be simply no need for these grammars to single out the constructions at issue. Second, I wonder why PZD refer to prescriptive rules at all. Note that they explicitly - and correctly claim that "convergence can only arise from usage" (under section heading: "Preposition placement in French relative clauses"). Thus, prescriptive rules are without any relevance to a study on putative convergence. Third, PZD quote Grevisse and Goose (2007) in order to support their claim. However, despite its subtitle Le bon usage, this grammar is much more descriptive in nature than prescriptive. Interestingly, PZD explicitly admit later on when quoting Grevisse and Goose (2007, p. 1327) again that the prepositions après "after", avant "before", contre "against", depuis "since", derrière "behind" and devant "in front of" are "perfectly acceptable in standard French" (under section heading: "Comparison with a native French model: Preposition orphaning") without a complement, at least in non-relative contexts. Note, however, that this also holds for other prepositions. In fact, Grevisse and Goose (2007, p. 1327f.) do point out that both in popular speech and in the "langue littéraire", prepositions like après "after", in particular, but also entre "in between", pendant "during", pour "for" and sans "without" may occur without their complement when this is a [-human] one. Moreover, the omission of [+human] complements is also "quite frequent", specifically with prepositions like après and dessus, while avec, sans and pour are only encountered in the "very familiar spoken language". There is, thus, no doubt that preposition orphaning is a well-attested feature in European French, a fact which represents a further crucial argument for PZD's argumentation against the contact-induced change of bare prepositions in Quebec French.

My last observation concerns an example encountered in the (European) French novel Zazie dans le métro by Raymond Queneau (p. 252), one of the colloquial French novels par excellence. This example is given (6): ${ }^{3}$

(6) Mais c'est plus moi qui courrai après.

"But as for me, I do no longer run after (him)."

Note that although the preposition occurs in a relative clause, the construction differs from constructions like (1) or (2), since the preposition cannot be pied-piped, i.e. preposed together with its complement to a higher CP-position. Moreover, (6) represents a clear case of preposition orphaning which occurs INSIDE a relative clause, namely a subject relative clause. This, however, is in stark contradiction to PZD's claim that preposition orphaning in relative clauses is excluded (under section

3 Example from R. Queneau, Zazie dans le métro. Paris: Gallimard (1959). 
heading: "Comparison with a native French model: Preposition orphaning" and passim).

Thus, example (6) provides another good illustration of the high complexity of constructions with bare prepositions and shows that more insight into these prepositions in both French and English is still needed. What is clear, however, thanks to PZD, is that the Canadian French constructions at issue may certainly not be considered a result of a contact-induced change triggered by code-switching of English-French bilinguals.

\section{References}

Grevisse, M., \& Goosse, A. (2007). Le bon usage Grammaire française ( $14^{\ominus}$ edition). Brussels: De Boek \& Larcier.

Jones, M. A. (1996). Foundations of French syntax. Cambridge: Cambridge University Press.

Poplack, S., \& Levey, S. (2010). Contact-induced grammatical change: A cautionary tale. In P. Auer \& J. E. Schmidt (eds.), Language and space: An international handbook of linguistic variation (vol. 1): Theories and methods, pp. 391-419. Berlin: de Gruyter.

Poplack, S., Zentz, L., \& Dion, N. (2011). Phrasefinal prepositions in Quebec French: An empirical study of contact, code-switching and resistance to convergence. Bilingualism: Language and Cognition, doi: $10.1017 /$ S1366728911000204. Published by Cambridge University Press, 11 August 2011.

Porquier, R. (2001). "Il m'a sauté dessus", “je lui ai couru après": un cas de postposition en français. Journal of French Language Studies, 11, 123-134.

Radford, A. (1997). Syntactic theory and the structure of English: A minimalist approach. Cambridge: Cambridge University Press.

Riegel, M., Pellat, J. C., \& Rioul, R. (2008). Grammaire méthodique $d u$ français $\left(3^{\ominus}\right.$ edition). Paris: Presses Universitaires de France.

Rowlett, P. (2007). The syntax of French. Cambridge: Cambridge University Press. 